\section{Jordan's Principle remains in limbo}

$\mathrm{F}$ ederal and provincial governments have failed profoundly to live up to their obligations in the year since the House of Commons unanimously passed Jordan's Principle to end jurisdictional disputes over social, education and medical services for First Nation children, advocates charge.

Cindy Blackstock, executive director of the First Nation Child and Family Caring Society says the federal and provincial governments remain stuck in the same bureaucratic and jurisdictional quagmire that hampers service provision to aboriginal children.

Although it is difficult to get up-todate information from First Nations, the society is tracking nearly 400 Aboriginal children across Canada who are going without essential services because neither Ottawa nor the provinces can decide who should pay. "Governments are still putting jurisdictional issues ahead of the welfare of children," Blackstock says.

Jordan's Principle was established in response to the death of 5-year-old Jordan River Anderson, a child from Norway House First Nation who suffered from a rare muscular disorder that required years of medical treatment in a Winnipeg hospital. Negotiations on who would pay the costs to return Jordan to his family in his home community 800 kilometres north of Winnipeg went on for nearly 3 years.

Anderson died in hospital while the 2 governments bickered over the costs of returning him to his home. No agreement was reached about which level of government would pay for his special medical needs.

In response to his death, the House of Commons reached a consensus on Jordan's Principle, which stipulates that in the event of a jurisdictional dispute over funding for a First Nation child, the government of first contact will pay for services and seek cost-sharing later. Ottawa and the provinces agreed to negotiate bilateral agreements to implement the resolution and establish a protocol for resolving disputes (CMAJ 2008;178[3]:277 and $C M A J$ 2007;177[4]:321).

Although several provinces have expressed support for Jordan's Principle, advocates say there has been no real progress in actually delivering on the vision.

Last spring, 37 children with special needs from Norway House First Nation were denied social and medical services because of a jurisdictional impasse (CMAJ 2008;178[12]:1535-6).

Aboriginal leaders and children's advocates were enraged. Federal Indian Affairs Minister Chuck Strahl and former health minister Tony Clement indicated a formal agreement would be in place by May 31 to address the needs of all First Nation children in Manitoba. In September, the 2 governments issued a statement promising that all necessary services will be provided while officials "formalize and finalize processes including a dispute resolution mechanism."

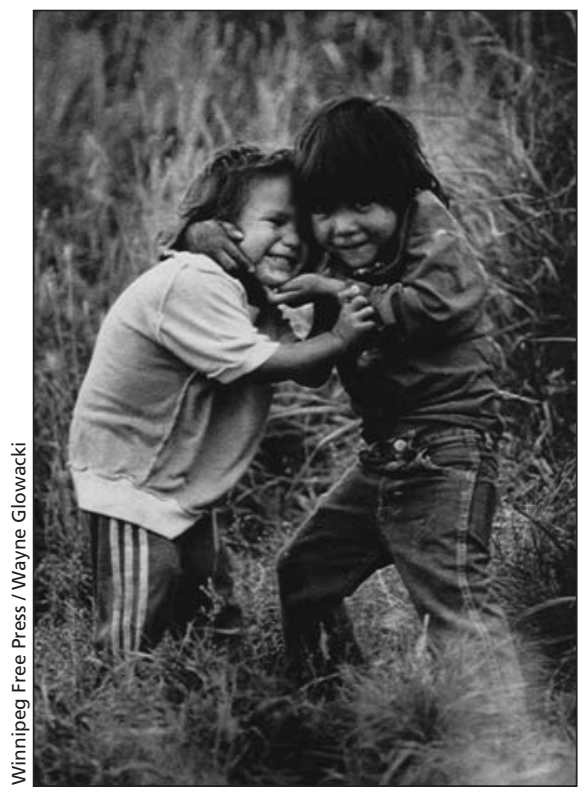

The Canadian Paediatric Society has called for a national strategy to improve the health of Aboriginal children and youth.

Kerri Irvin-Ross, Manitoba's minister of healthy living, says the agreement ensures all disputes will be resolved without denying children services. "What's important is that as a province we work with the federal government to provide these services."

But concerns have arisen that during the deal-making both governments sought to limit the services they are compelled to provide.
Blackstock believes Ottawa and Manitoba have specifically restricted Jordan's Principle to "complex medical needs," while excluding other social or educational services that were clearly envisioned by the original parliamentary resolution.

Concerns over a lack of progress in implementing Jordan's Principle prompted Dr. Jon Gerrard, leader of the Manitoba Liberal Party, to introduce a private member's bill in the Manitoba legislature earlier this year that would force the 2 levels of government to live up to the spirit and scope of the original resolution.

The bill won the support of the Progressive Conservatives, the official opposition in Manitoba, but was voted down by the governing New Democrats of Premier Gary Doer. Gerrard, who plans to reintroduce the bill next spring, says the 2 governments are clearly engaged in the same bureaucratic stalling that led to the Anderson tragedy.

In particular, Gerrard is concerned the governments are still preoccupied with completing "case conferences" to assess the specific needs of the Norway House children, despite the fact band officials have already completed detailed medical records and needs assessments.

"In Jordan's case, the 2 levels of government were involved in case conferences for 3 or 4 years and were never able to resolve the issue. The fact that they are going about this in the same way they did before is very disturbing."

The issue of Jordan's Principle received very little attention in the recent federal election. Both the federal Liberals and New Democrats endorse full implementation, but Blackstock says the Conservatives did not respond to a questionnaire from the Assembly of First Nations that touched on the issue.

"The government would not even respond to the question on Jordan's Principle," says Blackstock. "That has us very concerned." - Dan Lett, Winnipeg, Man.

DOI:10.1503/cmaj.081756 